\title{
Proteocephalid cestode infection in alien fish, Cichla piquiti Kullander and Ferreira, 2006 (Osteichthyes: Cichlidae), from Volta Grande reservoir, Minas Gerais, Brazil
}

\author{
Martins, ML. ${ }^{\mathrm{a} *}$, Pereira Jr., $J .^{\mathrm{b}}$, De Chambrier, A. ${ }^{\mathrm{c}}$ and Yamashita, MM. ${ }^{\mathrm{a}}$

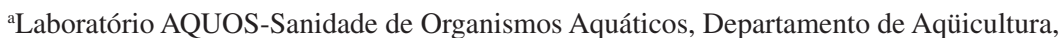 \\ Centro de Ciências Agrárias - CCA, Universidade Federal de Santa Catarina - UFSC, \\ Rod. SC 404, Km 3, CEP 88040-900, Florianópolis, SC, Brazil \\ 'baboratório de Ictioparasitologia, Departamento de Ciências Morfo-Biológicas, \\ Universidade Federal do Rio Grande - FURG, CEP 96650-900, RS, Brazil \\ 'Invertebrate Department, Natural History Museum, \\ P.O. Box 6434, 1211 Geneva, 6, Switzerland \\ *e-mail: mlaterca@cca.ufsc.br
}

Received September 25, 2007 - Accepted December 13, 2007 - Distributed February 28, 2009

\begin{abstract}
This work evaluates the variation of the parasitological indexes in 114 Cichla piquiti Kullander and Ferreira, 2006 (tucunaré) infected by two proteocephalid species (Cestoda) for the period of August 1999 to June 2001 in the Volta Grande reservoir, MG, Brazil. The relation between the parasitosis with rainfall and water quality (pH, electric conductivity, oxygen, chlorophyll, transparency and temperature) is discussed. Prevalence of Proteocephalus macrophallus (Diesing, 1850) and/or P. microscopicus (Woodland, 1935) was 83.3\%, mean intensity 110.8 and mean abundance 100.7 during the period. A hundred percent prevalence was reported in August and December 1999, April and December 2000 and June 2001. The largest mean intensities of 122.7 (October 1999), 158.8 (December 1999), 96.4 (February 2000), 400.7 (April 2000), 215.6 (October 2000) and 136.4 (December 2000) were observed. Abiotic factors may favour the development of the species of the food chain that sustain the organisms in the diet of "tucunaré", but in this case, there was no correlation $(\mathrm{P}>0.05)$ between the values of prevalence, mean intensity and mean abundance with the rainfall and water quality. At the same time, these organisms may constitute the intermediate hosts of cestodes. The time-course between the fish species development and the parasitosis manifestation in the definitive host can explain the lack of correlation between the parasitological indexes and abiotic factors. The predation on small fishes and cannibalism described for "tucunaré" might explain the high values of prevalence and intensity of infection. The results are also related to the exotic condition of the host in the reservoir.
\end{abstract}

Keywords: Tucunare, alien fish, parasitism, Proteocephalidae, hydroelectric reservoir.

\section{Infecção por cestóides proteocefalídeos em peixe introduzido, Cichla piquiti (Osteichthyes: Cichlidae), no reservatório de Volta Grande, Minas Gerais, Brasil}

\begin{abstract}
Resumo
Este estudo avalia a variação nos índices parasitológicos de 114 espécimes de Cichla piquiti Kullander e Ferreira, 2006 (tucunaré) infectados por duas espécies de proteocefalídeos (Cestoda) entre agosto de 1999 e junho de 2001 no reservatório de Volta Grande, MG, Brasil. A relação entre a parasitose e os valores de pluviosidade e qualidade de água ( $\mathrm{pH}$, condutividade elétrica, oxigênio, clorofila, transparência e temperatura) é discutida. A prevalência de Proteocephalus macrophallus (Diesing, 1850) e/ou P. microscopicus (Woodland, 1935) foi 83,3\%, intensidade média 110,8 e abundância média 100,7 durante todo o período. Prevalência de $100 \%$ foi observada em agosto e dezembro de 1999, abril e dezembro de 2000 e junho de 2001. As maiores intensidades médias foram 122,7 em outubro de 1999; 158,8 em dezembro de 1999; 96,4 em fevereiro de 2000; 400,7 em abril de 2000; 215,6 em outubro de 2000; e 136,4 em dezembro de 2000. Fatores abióticos podem favorecer o desenvolvimento de espécies que sustentam a alimentação do "tucunaré", mas, neste caso, não houve correlação $(\mathrm{P}>0,05)$ entre os valores de prevalência, intensidade média e abundância média com a pluviosidade e qualidade de água no reservatório. Ao mesmo tempo, estes organismos podem constituir hospedeiros intermediários de cestóides. A relação entre o desenvolvimento da espécie hospedeira e
\end{abstract}


a manifestação da parasitose no hospedeiro definitivo pode explicar a falta de correlação entre os índices parasitológicos e os fatores abióticos. A predação de pequenos peixes e o canibalismo descrito para o "tucunaré" explica a elevada prevalência e intensidade de infecção, favorecido pela condição exótica do hospedeiro no reservatório.

Palavras-chave: Tucunaré, peixe introduzido, parasitismo Proteocephalidae, reservatório.

\section{Introduction}

Derived from the Amazon basin (Gomiero and Braga, 2004b), Cichla piquiti Kullander and Ferreira, 2006 ("tucunaré"), introduced into other Brazilian hydrographic basins such as Paraná-Paraguai, São Francisco and others in northeastern Brazil, has a great importance in the region due to its flesh quality (Gomiero and Braga, 2004a) showing fast adaptation to hydroelectric reservoirs (Takemoto and Pavanelli, 1996; Gomiero and Braga, 2004b). A strong reason for its study is supported by their being preferred in sport fishing (Kitamura et al., 2002). However the consequence of the introduction of this host on the parasites populations or communities structure is not known, and commonly it is pointed as responsible by great damages, especially to the native populations, with which it starts to live together (Gomiero and Braga, 2004b)

Moderate infection rates by Proteocephalidea have been registered in fish from several parts of the world, as in Bohemian (Scholz, 1987), Mexico (García-Prieto et al., 1996; Moravec et al., 2002), Nicaragua (AguirreMacedo et al., 2001) and Galícia Coast (Outeiral et al., 2002). However situations of high parasitological indexes from fish infected by Proteocephalidae, in Mexico (PérezPonce de León et al., 1995), Paraguay (de Chambrier and Vaucher, 1994; 1997; 1999), and Slovákia (Hanzelová et al., 2001) have also been described. In Brazil, this group of parasites has been studied in several fish species from the Paraná River (Rego and Pavanelli, 1987; Pavanelli and Santos, 1990; 1991; de Chambrier and Rego, 1995; de Chambrier et al., 1999; 2006; Rego et al., 1998; 1999; Pavanelli and Takemoto, 2000; Takemoto and Pavanelli, 2000; Machado et al., 2000; Rego, 2002; de Chambrier, 2003) and from the States of Pará, Mato Grosso, Espírito Santo and Amazonas (Rego and Pavanelli, 1990; de Chambrier and Rego, 1994; de Chambrier and Vaucher, 1997, de Chambrier, 2001; 2003; de Chambrier et al., 2004ab; 2005; de Chambrier and Scholz, 2005).

Studies like this on the proteocephalid biology in alien fish are not frequent, the ecological interpretation of data relative to population distribution of these parasites is sometimes merely speculative. Poulin (1992) observed that Proteocephalidea has not a huge host specificity. On the other hand, de Chambrier and Vaucher (1999) treated 59 proteocephalidean species distributed in 17 genera in the Parana basin. They observed on 53 species collected in Paraguay, that a huge majority (98\%) shows a strict specificity of oioxene type according to Euzet and Combes (1980). Nevertheless, the studies on its life cycle are few and poorly understood (Jarecka and Doby, 1965; Willemse, 1969; Priemer, 1987; Scholz, 1991;
1993; Moravec, 2001). Scholz (1999) made a detailed overview of the Proteocephalus life cycle from the Palearctic Region.

This work evaluated the influence of the rainfall indexes and water quality in $C$. piquiti infected by two species of proteocephalid cestodes, in the Volta Grande reservoir, MG, Brazil. Based in available data on the host biology and, on similar species of proteocephalids, a discussion was elaborated that seeks to explain the obtained results.

\section{Material and Methods}

During the period of August 1999 to June 2001, a total of 114 fish were bimonthly captured with net and transported in ice for immediate parasitological exam. The collection was conducted in the hydroelectric power station of Volta Grande reservoir (CEMIG), Grande River, MG, Brazil (21 ${ }^{\circ} 46^{\prime} 14^{\prime \prime} \mathrm{S}$ and $\left.42^{\circ} 32^{\prime} 20^{\prime \prime} \mathrm{W}\right)$. In each sample, the aquatic characteristics such as $\mathrm{pH}$, electric conductivity, dissolved oxygen, chlorophyll, transparency and temperature were performed. The rainfall during the period of collection was measured by the CEMIG Hydrology Department. It was not possible to obtain water quality data in February 2000. Worms found in the intestine were isolated and fixed in hot $4 \%$ formaldehyde solution and stored in $75 \%$ ethanol. Entire tapeworms were stained with Mayer's hydrochloric carmine (modified from Langeron, 1949), differentiated in acid ethanol, dehydrated through a gradual ethanol series, cleared with Eugenol or beechwood creosote and mounted as whole mounts in Canada balsam. Thick cross hand-cutting sections of the proglottides were stained following the same procedure; fragments of the strobila were embedded in paraffin wax, transversely sectioned at $13-19 \mu \mathrm{m}$, stained with Weigert's hematoxylin and counterstained with $1 \%$ eosin B and mounted in Canada balsam (see de Chambrier and Pertierra, 2002).

The prevalence, mean intensity and mean abundance of infection were calculated according to Bush et al. (1997). The Pearson correlation analysis was used to verify the significance between the values of rainfall, prevalence and mean intensity of infection. The number of parasites was compared among the months by Oneway ANOVA and F test $(\alpha<0.05)$ and for average comparison Scheffé test according to Banzatto and Kronka (1995).

Specimens of P. macrophallus and P. microscopicus studied were deposited at the Natural History Museum, Geneva, Switzerland (respectively MHNG Collection 
number INVE 34677, 35401, 35402 and INVE 34065, 35403) and at the Helminthological Collection of Instituto Oswaldo Cruz (CHIOC), number 36845a-b (P. macrophallus) and 36846a-b (P. microscopicus).

\section{Results}

There was no variation in electric conductivity and water $\mathrm{pH}$ in the studied period, in spite of the low transparency in April 2000 (2.1 m). Months with the highest temperatures were December $2000\left(27.8{ }^{\circ} \mathrm{C}\right)$, February $\left(28.4^{\circ} \mathrm{C}\right)$ and April $2001\left(28.0^{\circ} \mathrm{C}\right)$ while the lowest were in June $\left(21.8^{\circ} \mathrm{C}\right)$ and August $2000\left(22.9^{\circ} \mathrm{C}\right)$. The lowest values of dissolved oxygen occurred in December 2000 (7.47 mg.L. ${ }^{-1}$ ) and February 2001 (6.73 mg.L ${ }^{-1}$ ). The algae biomass measured by chlorophyll analysis showed its highest value $\left(11.30 \mu \mathrm{g} . \mathrm{L}^{-1}\right)$ in April of 2000, but in the other months varied from 1.70 to $5.30 \mu \mathrm{g} . \mathrm{L}^{-1}$. Significant decrease in rainfall was found in April 2000 $(53 \mathrm{~mm})$ and the highest indexes (1,617 and 1,582 $\mathrm{mm})$ were observed in December 2000 and February 2001, respectively (Table 1). There was no significant relation $(\mathrm{P}>0.05)$ of the prevalence rates, intensity of infection, mean abundance with the rainfall indexes and water characteristics.

Cestode species identified as Proteocephalus macrophallus (Diesing, 1850) Scholz, de Chambrier, Prouza and Royero 1996 and Proteocephalus microscopicus Woodland, 1935, were found during the whole period with total prevalence rate $83.3 \%$, mean intensity of infection 110.8 and mean abundance 100.7 parasites. The lowest prevalence rates were reported in June and August 2000, respectively 13.7 and 8.2, and the highest (100\%) in August, December 1999; April, December 2000 and June 2001. Nevertheless, increased mean intensity of infection varied from 122.7 to 400.7 parasites per host from October 1999 to April 2000 and 136.4 to 215.6 in October and December 2000, respectively (Table 2).

\section{Discussion}

In this work no significant relation $(\mathrm{P}>0.05)$ of the prevalence rates, intensity of infection, mean abundance with the rainfall indexes and water quality was observed. The oligotrophic characteristic of the reservoirs in Brazil was defined by Henry (1999). The lowest water transparency and the highest algae biomass in April 2000 coincided with $100 \%$ prevalence and the highest mean intensity of cestodes.

In cultured fish, Scholz (1987) and Scholz et al. (1997) related Proteocephalus percae (Müller, 1780) and Proteocephalus macrocephalus Creplin, 1825, respectively in perch and eel. Cichla piquiti is commonly found in sport fishing in Brazil. From this point of view, this work contributes to the knowledge of parasite fauna of this fish. It must be remembered that if the fish is maintained in fish farming the numbers of mean intensity here observed can cause disease.

Mackie et al. (1983), related domination of cestode infections by Ligula intestinalis Linnaeus, 1758 and Proteocephalus ambloplitis Leidy, 1887 among fish parasitic fauna in Guelph Lake. However, the prevalence rate was higher than that observed in fish from downstream. When compared to the present study, low prevalence rates and mean intensities were verified in fish parasitized by $P$. ambloplitis related by Mackie et al. (1983), P. percae by Scholz (1987), P. brooksi by García-Prieto et al. (1996); in fish parasitized by proteocephalids studied by Aguirre-Macedo et al. (2001); Proteocephalus longicollis Zeder, 1800 and Proteocephalus torulosus Batsch, 1786 studied by Hanzelová et al. (2001) and in fish parasitized by $P$. macrocephalus from the estuarine bays in the Iberian Peninsula studied by Outeiral et al. (2002). This is an example that must be discussed in which the parasitic fauna from reservoirs may vary in their parasitological indexes. The infection rates here observed were higher than those reported by other authors in other countries. This is especially true when analysing

Table 1. Mean values of the rainfall values (RF) and water quality measured in the Volta Grande Reservoir, Minas Gerais State, Brazil, between April 2000 and April 2001 during the collection of fish.

\begin{tabular}{|c|c|c|c|c|c|c|c|}
\hline Months & $\begin{array}{c}\text { RF } \\
(\mathbf{m m})\end{array}$ & $\begin{array}{c}\text { Transparency } \\
\text { (m) }\end{array}$ & $\begin{array}{c}\text { Chlorophyll } \\
\left(\mu \mathrm{g} . \mathrm{L}^{-1}\right)\end{array}$ & pH & $\begin{array}{c}\text { Conductivity } \\
\left(\mu \mathrm{S} . \mathrm{cm}^{-1}\right)\end{array}$ & $\begin{array}{c}\text { Temperature } \\
\left({ }^{\circ} \mathbf{C}\right)\end{array}$ & $\begin{array}{l}\text { Oxygen } \\
\left(\mathrm{mg}^{\left.-\mathbf{L}^{-1}\right)}\right.\end{array}$ \\
\hline Aug 1999 & 6 & 2.85 & 4.70 & 7.16 & 34.67 & 21.10 & 7.50 \\
\hline Oct 1999 & 7 & 3.60 & 3.90 & 6.40 & 34.33 & 25.33 & 7.10 \\
\hline Dec 1999 & 241 & 3.00 & - & 6.66 & 34.00 & 26.20 & 7.63 \\
\hline Apr 2000 & 53 & 2.15 & 11.3 & 6.41 & 35.00 & 26.87 & 8.17 \\
\hline Jun 2000 & 0 & 3.85 & 1.70 & 6.23 & 35.00 & 21.83 & 8.90 \\
\hline Aug 2000 & 249 & 5.35 & 5.30 & 7.08 & 29.00 & 22.93 & 8.50 \\
\hline Oct 2000 & 669 & 3.25 & 3.00 & 6.87 & 35.00 & 26.93 & 7.80 \\
\hline Dec 2000 & 1,617 & 3.90 & 3.00 & 7.52 & 35.33 & 27.83 & 7.47 \\
\hline Feb 2001 & 1,582 & 7.30 & 2.60 & 7.90 & 34.33 & 28.40 & 6.73 \\
\hline Apr 2001 & 747 & 5.30 & 4.50 & 6.92 & 29.00 & 28.00 & 8.43 \\
\hline
\end{tabular}


Table 2. Parasitological indexes and biometry of Cichla piquiti parasitized with Proteocephalus macrophallus and Proteocephalus microscopicus from Volta Grande Reservoir, MG, Brazil. Mean values and variation in parentheses. Infected fish/examined fish (IF/EF), prevalence (P), mean intensity (MI), mean abundance (MA). Different letters indicate significant difference among the months $(\mathrm{P}<0.05)$.

\begin{tabular}{|c|c|c|c|c|c|c|}
\hline Months & Fish weight (g) & Fish length $(\mathrm{cm})$ & IF/EF & $\mathbf{P}(\%)$ & MI & MA \\
\hline Aug/1999 & $\begin{array}{c}201.5 \\
(160-241)\end{array}$ & $\begin{array}{c}24.5 \\
(23-25)\end{array}$ & $8 / 8$ & 100 & $\begin{array}{l}64.7 \mathbf{a b} \\
(2-139)\end{array}$ & 64.7 \\
\hline Oct/1999 & $\begin{array}{c}275.5 \\
(203-391)\end{array}$ & $\begin{array}{c}27.2 \\
(25-29)\end{array}$ & $8 / 10$ & 80 & $\begin{array}{c}122.7 \mathbf{a b} \\
(8-288)\end{array}$ & 98.2 \\
\hline Dec/1999 & $\begin{array}{c}704.9 \\
(275-2500)\end{array}$ & $\begin{array}{c}32.3 \\
(27-50)\end{array}$ & $13 / 13$ & 100.0 & $\begin{array}{c}158.8 \mathbf{a b} \\
(10-264)\end{array}$ & 158.8 \\
\hline $\mathrm{Feb} / 2000$ & $\begin{array}{c}212.0 \\
(13-638)\end{array}$ & $\begin{array}{c}18.9 \\
(10-36)\end{array}$ & $5 / 6$ & 83 & $\begin{array}{l}96.4 \mathbf{a b} \\
(3-223)\end{array}$ & 80.3 \\
\hline Apr/2000 & $\begin{array}{c}384.3 \\
(180-765)\end{array}$ & $\begin{array}{c}27.7 \\
(22-35)\end{array}$ & $3 / 3$ & 100.0 & $\begin{array}{c}400.7 \mathbf{b} \\
(65-1021)\end{array}$ & 400.7 \\
\hline Jun/2000 & $\begin{array}{c}697.0 \\
(30-1034)\end{array}$ & $\begin{array}{c}34.3 \\
(14-43)\end{array}$ & $7 / 10$ & 70 & $\begin{array}{l}13.7 \mathbf{a} \\
(3-32)\end{array}$ & 9.6 \\
\hline Aug/2000 & $\begin{array}{c}1781.3 \\
(165-2750)\end{array}$ & $\begin{array}{c}44.9 \\
(23-54)\end{array}$ & $4 / 11$ & 36 & $\begin{array}{c}8.2 \mathbf{a} \\
(2-23)\end{array}$ & 3.0 \\
\hline Oct/2000 & $\begin{array}{c}768.0 \\
(168-1503)\end{array}$ & $\begin{array}{c}38.9 \\
(23-49)\end{array}$ & $8 / 11$ & 73 & $\begin{array}{c}215.6 \mathbf{a b} \\
(4-629)\end{array}$ & 156.8 \\
\hline Dec/2000 & $\begin{array}{c}978.5 \\
(470-2500)\end{array}$ & $\begin{array}{c}37.9 \\
(30-53)\end{array}$ & $11 / 11$ & 100 & $\begin{array}{l}136.4 \mathbf{a b} \\
(16-422)\end{array}$ & 136.4 \\
\hline $\mathrm{Feb} / 2001$ & $\begin{array}{c}1174.2 \\
(205-2200)\end{array}$ & $\begin{array}{c}40.0 \\
(26-52)\end{array}$ & $9 / 10$ & 90 & $\begin{array}{c}23.7 \mathbf{a b} \\
(3-39)\end{array}$ & 21.3 \\
\hline Apr/2001 & $\begin{array}{c}226.3 \\
(94-710)\end{array}$ & $\begin{array}{c}25.0 \\
(19-37)\end{array}$ & $9 / 11$ & 82 & $\begin{array}{c}51.7 \mathbf{a b} \\
(12-304)\end{array}$ & 42.3 \\
\hline Jun/2001 & $\begin{array}{c}716.3 \\
(290-1015) \\
\end{array}$ & $\begin{array}{c}34.7 \\
(27-41) \\
\end{array}$ & $10 / 10$ & 100 & $\begin{array}{c}36.9 \text { ab } \\
(7-98)\end{array}$ & 36.9 \\
\hline Total & $\begin{array}{c}676.6 \\
(13-2750)\end{array}$ & $\begin{array}{c}32.2 \\
(10-54)\end{array}$ & $95 / 114$ & 83 & $\begin{array}{c}110.8 \\
(2-1021)\end{array}$ & 100.7 \\
\hline
\end{tabular}

Table 2 showing mean intensity of infection varying from 122.7 to 400.7 parasites. The highest number of adult cestodes $(1,021)$ observed in this work is not common for fish in a natural environment. But this fact may in part be explained by the fact that the studied reservoir may present variation in the fish population. The exact fish population of this reservoir is not estimated but the larger number of captured species in the experiments of Braga and Gomiero (1997) were Plagioscion squamosissimus Heckel, 1840, Pimelodus maculatus Lacépède, 1803, Astyanax bimaculatus Ortega and Vari, 1986, Leporinus friderici Ortega and Vari, 1986 and C. piquiti. According to Latini and Petrere Jr. (2004) the richness and diversity of the local fish community in the Basin of Doce River, Minas Gerais State, Brazil, was affected by the presence of the introduced Cichla monoculus Spix, 1831. These authors comment that the parental care and the high competitiveness of this cichlid put the alien fish on top of the food web in lakes. This might explain the high number of parasites found in this study, possibly also due to a small size of the parasite.

Despite the significant number of 82 examined Rhamdia guatemalensis Günther, 1864, only 7 (9\%) of these fishes were parasitized by $P$. brooksi, as related by Moravec et al. (2002). As a result of the moderate infections, mean intensities were 1 to 5.5 parasites. These data differ from the present study where high parasitological indexes occurred in C. piquiti in Brazil. As in the present work, Moravec et al. (2002) did not observe seasonal variation. A hundred percent of prevalence in C. piquiti was similar to that reported in fish parasitized by Proteocephalus chamelensis Pérez Ponce de Leon, Brooks and Berman, 1995 (Pérez Ponce de León et al., 1995).

In Brazil, Rego and Pavanelli (1987) have reported proteocephalidcestodesinPaulicealuetkeniSteindachner, 1875, from Itaipu Reservoir, Foz do Iguaçú and Pavanelli and Santos (1990) described Cangatiella arandasi, in Parauchenipterus galeatus Linnaeus, 1766, from Porto Rico, Paraná. Studying proteocephalids from the Paraná River, Pavanelli and Santos (1991) observed Travassiella avitellina Rego and Pavanelli, 1987, C. arandasi and Proteocephalus serrasalmus Rego and Pavanelli, 1990. However, proteocephalid cestodes were also present in other fish species collected from the States of Pará, Mato Grosso, Espírito Santo and Amazonas (Rego and Pavanelli, 1990; de Chambrier and Rego, 1994). 
The prevalence rates and the mean intensity of infection observed by Machado et al. (1994) in Pseudoplatystoma corruscans Agassiz, 1829, by de Chambrier and Rego (1994) in P. luetkeni and by de Chambrier (2003) in Sorubim lima Schneider 1801 were lower than those reported here in $C$. piquiti. Similar proteocephalids prevalence rates were also observed in fish from the Paraná River (Takemoto and Pavanelli, 2000). On the other hand, the mean intensity (3.1 to 8.7) was lower than that related in $C$. piquiti from Volta Grande Reservoir. According to Takemoto and Pavanelli (2000), only Spatulifer maringaensis Pavanelli and Rego, 1989, showed $85 \%$ prevalence followed by mean intensity of 76 parasites. From fish examined from the Paraná River, $88.8 \%$ were parasitized by at least one species of proteocephalid. This is an example of the high occurrence of this group of cestodes in Brazilian fish. In C. monoculus examined by Machado et al. (2000) the results revealed similarity in the prevalence, mean intensity and mean abundance when compared to that obtained in this study. Moreover, the previous results with $P$. macrophallus and/or P. microscopicus in C. monoculus (Takemoto and Pavanelli, 1996) suggest its role as opportunistic parasites. In this study, the increased parasitological indexes in $C$. piquiti may be related to the fact that this fish is an alien species in the Volta Grande Reservoir. This fact corroborates the findings of Priemer (1987) who studied the life cycle of Proteocephalus exiguus La Rue, 1911 in Atlantic salmon. On the other hand, in experimental conditions, Willemse (1969) observed decreased survival of proteocephalid in the alien host. The high specificity of proteocephalids in the intermediate host was related by Jarecka and Doby (1965). On the other hand, these authors did not observe this fact in the definitive host.

The results may be explained by the hypothesis of the exotic characteristic of the host, its piscivorous habit constituted by small fish of the same species as reported by Rabelo and Araújo-Lima (2002) and Gomiero and Braga (2004b). Nevertheless, Moravec (2001) suggested the possible transmission of the cestodes by ingestion of small fishes. The high intensity of infection of the parasitosis may result in decreased fish growth as supported by Scholz et al. (2004) and Priemer (1987). According to this topic, it is possible to infer that the proteocephalid parasitosis in small fishes by the ingestion of zooplankton (Priemer, 1987) contributes to improve the prevalence rates and the intensity of infection in the largest hosts. This hypothesis was reinforced with the findings of Takemoto and Pavanelli (1996) who studied proteocephalids from Cichla monoculus Spix, 1863 an alien fish in the Paraná River, South Brazil. These authors have also found $P$. microscopicus and $P$. macrophallus in high prevalence and intensity of infection. To date, Priemer (1987) attributed the high indexes of infection in introduced trout to its carnivorous habit in Germany. The high indexes observed in this study may be a result of these factors. As previously supported, little is known about population structure, the fish community and the trophic relations in the Volta Grande reservoir.

Among the factors that contribute to disease dissemination in fish are the host susceptibility, the fish stocking densities, the duration of infectious process, the introduction and the inadequate handling as supported by Reno (1998). Consequently, the trophic relations of this alien fish in the reservoir might be better understood to explain the elevated parasitological indexes found here. Moreover, the fact that few studies are realized in the tropical regions impairs the concluding results.

Acknowledgements - We thank the Hydroelectric Power Station of Minas Gerais (CEMIG), Brazil for field support and CNPq (National Council of Scientific and Technological Development) for a grant for the first author.

\section{References}

AGUIRRE-MACEDO, ML., SCHOLZ, T., GONZÁLEZSOLÍS, D., VIDAL-MARTÍNEZ, VM., POSEL, P., ARJONATORRES, G., SIU-ESTRADA, E. and DUMAILO, S., 2001. Larval helminthes parasitizing freshwater fishes from Atlantic Coast of Nicaragua. Comparative Parasitology, vol. 68, p. $42-51$.

BANZATTO, DA. and KRONKA, SN., 1995. Experimentação agrícola. Jaboticabal: FUNEP, 247p.

BRAGA, FMS. and GOMIERO, LM., 1997. Análise da pesca experimental realizada no reservatório de Volta Grande, Rio Grande (MG-SP). Boetim do Instituto de Pesca, vol. 24, no. 1, p. $131-138$.

BUSH, AO., LAFFERTY, KD., LOTZ, JM. and SHOSTAK, W., 1997. Parasitology meets ecology on its own terms: Margolis et al. revisited. Journal of Parasitology, vol. 83, no. 4, p. 575-583.

De CHAMBRIER, A., 2001. A new tapeworm from the Amazon, Amazotaenia yvettae n.gen., n.sp., (Eucestoda: Proteocephalidea) from the siluriform fishes Brachyplatystoma filamentosum and B. vaillanti (Pimelodidae). Revue Suisse de Zoologie, vol. 108, p. 303-316.

-, 2003. Systematic status of Manaosia bracodemoca Woodland, 1935 and Paramonticellia itaipuensis Pavanelli et Rego, 1991 (Eucestoda: Proteocephalidea), parasites of Sorubim lima (Siluriformes: Pimelodidae) from South America. Folia Parasitologica, vol. 50, no. 2, p. 121-127.

De CHAMBrIER, A. and REGO, AA., 1994. Proteocephalus sophiae n. sp. (Cestoda: Proteocephalidae), a parasite of the siluroid fish Paulicea luetkeni (Pisces: Pimelodidae) from the Brazilian Amazon. Revue Suisse de Zoologie, vol. 101, p. $361-368$

-, 1995. Mariauxiella pimelodi n. g., n. sp. (Cestoda: Monticelliidae): a parasite of pimelodid siluroid fishes from South America. Systematic Parasitology, vol. 30, no. 1, p. 57-65.

De CHAMBRIER, A. and PERTIERRA, AAG., 2002. Redescription of Travassiella avitellina Rego and Pavanelli, 1987 (Proteocephalidea: Monticelliidae, Zygobothriinae), a parasite of Paulicea luetkeni (Siluriformes) from South América. Memórias do Instituto Oswaldo Cruz, vol. 97, no. 5, p. $657-661$. 
De CHAMBRIER, A. and VAUCHER, C., 1994. Etude morphoanatomique et génétique de deux nouveaux Proteocephalus (Cestoda: Proteocephalidae) parasites de Platydoras costatus (L.), poisson siluriforme du Paraguay. Systematic Parasitology, vol. 27 , no. 3 , p. $173-185$.

-, 1997. Révision des cestodes (Monticelliidae) décrits par Woodland (1934) chez Brachyplatystoma filamentosum avec redéfinition des genres Endorchis Woodland, 1934 et Nomimoscolex Woodland, 1934. Systematic Parasitology, vol. 37 , no. 3, p. 219-233.

-, 1999. Proteocephalidae et Monticelliidae (Eucestoda: Proteocephalidea) parasites de poissons d'eau douce du Paraguay avec descriptions d'un genre nouveau et de dix espèces nouvelles. Revue Suisse de Zoologie, vol. 106, p. 165-240.

De CHAMBRIER, A. and SCHOLZ, T., 2005. Redescription of Houssayela sudobim (Eucestoda: Proteocephalidea), a parasite of Pseudoplatystoma fasciatum (Siluriformes) from the Amazon River. Systematic Parasitology, vol. 62, no. 3, p. 161-169.

De CHAMBrIER, A., REGO, AA. and VAUCHER, C., 1999. Euzetiella tetraphylliformis n. gen., n. sp., (Eucestoda: Proteocephalidae), parasite du poisson d'eau douce néotropical Paulicea luetkeni (Siluriforme, Pimelodidae). Parasite, vol. 6, no. 1, p. 43-47.

De CHAMBRIER, A., REGO, AA. and MARIAUX, J., 2004a. Redescription of Brooksiella praeputialis and Goezeella siluri (Eucestoda: Proteocephalidea), parasites of Cetopsis coecutiens (Siluriformes) from the Amazon and proposition of Goezeella danbrooksi sp.n. Revue Suisse de Zoologie, vol. 111, no. 1, p. 111-120.

De CHAMBRIER, A., ZEHNDER, MP., VAUCHER, C. and MARIAUX, J., 2004b. The evolution of the Proteocephalidea (Platyhelminthes, Eucestoda) based on an enlarged molecular phylogeny, with comments on their uterine development. Systematic Parasitology, vol. 57, no. 3, p. 159-171.

De CHAMBRIER, A., REGO, AA. and PERTIERRA, AAG., 2005. Redescription of two cestodes parasites (Eucestoda: Proteocephalidea), parasites of Phractocephalus hemioliopterus (Siluriformes) from the Amazon and proposition of Scholzia gen.n. Revue Suisse de Zoologie, vol. 112, no. 3, p. 735-752.

De CHAMBRIER, A., TAKEMOTO, RM. and PAVANELLI, GC., 2006. Nomimoscolex pertierrae n. sp. (Eucestoda: Proteocephalidea), a parasite of Pseudoplatystoma corruscans (Siluriforme: Pimelodidae) in Brazil and redescription of Nomimoscolex sudobim Woodland, 1935, a parasite of $P$. fasciatum. Systematic Parasitology, vol. 64, no. 3, p. 191-202.

EUZET, L. and COMBES, C., 1980. Les problèmes de l'espèce chez les animaux parasites. Mémoires Societé Zoologique de France, vol. 40, p. 239-285.

GARCÍA-PRIETO, L., RODRÍGUEZ, LM. and PÉREZPONCE De LEÓN, G., 1996. Proteocephalus brooksi n. sp. (Cestoda: Proteocephalidae) in the Neotropical freshwater fish Rhamdia guatemalensis (Siluriformes: Pimelodidae) from lake Catemaco, Veracruz, Mexico. Journal of Parasitology, vol. 82, no. 6, p. 992-997.

GOMIERO, LM. and BRAGA, FMS., 2004a. Reproduction of species of the genus Cichla in a reservoir in Southeastern Brazil. Revista Brasileira de Biologia = Brazilian Journal of Biology, vol. 64, no. 3b, p. 613-624.
GOMIERO, LM. and BRAGA, FMS., 2004b. Cannibalism as the feeding behaviour of Tucunarés introduced in Southeast Brazil. Revista Brasileira de Biologia = Brazilian Journal of Biology, vol. 64, no. 3b, p. 625-632.

HANZELOVÁ, V., SPAKULOVÁ, M. and TURCEKOVÁ, L., 2001. Diversity of endoparasitic helminths of fish from the lake Morské oko, Eastern Slovakia. Helminthologia, vol. 38, no. 3, p. 139-143.

HENRY, R., 1999. Ecologia de reservatórios: estrutura, função e aspectos sociais. Botucatu; São Paulo: Fundibio; Fapesp. $799 \mathrm{p}$

JARECKA, L. and DOBY, JM., 1965. Contribution à l'étude du cycle évolutif d'um Cestode du genre Proteocephalus parasite de Coregonus fera, em provence du Lac Léman. Annales de Parasitologie, vol. 40, p. 433-443.

KITAMURA, PC., QUEIROZ, JF., LOPES, RB., CASTRO Jr., FG. and BOYD, CE., 2002. Environmental and economic assessment of fee-fishing in São Paulo State, Brazil. Journal of Applied Aquaculture, vol. 12, no. 4, p. 23-41.

LANGERON, M., 1949. Précis de Microscopie. Paris: Masson and Cie, 1429p.

LATINI, AO. and PETRERE Jr., M., 2004. Reduction of a native fish fauna by alien species: an example from Brazilian freshwater tropical lakes. Fisheries Management and Ecology, vol. 11 , no. 2 , p. 71-79.

MACHADO, MH., PAVANELLI, GC. and TAKEMOTO, RM., 1994. Influence of host's sex and size on endoparasitic infrapopulations of Pseudoplatystoma corruscans and Schizodon borelli (Osteichthyes) of the High Paraná River, Brazil. Revista Brasileira de Parasitologia Veterinária, vol. 3, no. 2 , p. 143-148.

MACHADO, PM., ALMEIDA, SC., PAVANELLI, GC. and TAKEMOTO, RM., 2000. Ecological aspects of endohelminths parasitizing Cichla monoculus Spix, 1831 (Perciformes: Cichlidae) in the Paraná River near Porto Rico, State of Paraná, Brazil. Comparative Parasitology, vol. 67, p. 210-217.

MACKIE, GL., MORTON, WB. and FERGUSON, MS., 1983. Fish parasitism in a new impoudment and differences upstream and downstream. Hydrobiologia, vol. 99, p. 197-205.

MORAVEC, F., 2001. Common sculpin Cottus gobio as a natural paratenic host of Proteocephalus longicollis (Cestoda: Proteocephalidae), a parasite of salmonids, in Europe. Diseases of Aquatic Organisms, vol. 45, no. 2, p. 155-158.

MORAVEC, F., MENDOZA-FRANCO, E., VIVASRODRÍGUEZ, C., VARGAS-VÁZQUEZ, J. and GONZÁLEZSOLÍS, D., 2002. Observations on seasonal changes in the occurrence and maturation of five helminth species in the pimelodid catfish, Rhamdia guatemalensis, in the cenote (=sinkhole) Ixin-há, Yucatán, Mexico. Acta Societas Zoologicae Bohemicae, vol. 66, p. 121-140.

OUTEIRAL, S., ALVAREZ, MF., IGLESIAS, R., PANIAGUA, E. and SANMARTÍN, ML., 2002. Non-digenean parasites of eels from estuaries in North-west Spain. Helminthologia, vol. 39, no. 2, p. 91-97.

PAVANELLI, GC. and SANTOS, MHM., 1990. Cangatiella arandasi gen. sp. n. (Cestoda: Proteocephalidae) parasito de Parauchenipterus galeatus (Siluriformes: Auchnipteridae) do rio Paraná. Revista Brasileira de Zoologia, vol. 7, p. 535-539. 
-, 1991. Proteocefalídeos parasitos de peixes, em especial pimelodídeos do rio Paraná, Paraná. Revista Unimar, vol. 13, no. 2, p. 147-162.

PAVANELLI, GC. and TAKEMOTO, RM., 2000. Aspects of the ecology of proteocephalid cestodes, parasites of Sorubim lima (Pimelodidae) of the upper Paraná River, Brazil: II. Interspecific associations and distribution of gastrointestinal parasites. Revista Brasileira de Biologia = Brazilian Journal of Biology, vol. 60 , no. 4, p. 585-590.

PÉREZ-PONCE De LEÓN, G., BROOKS, DR. and BERMAN, R., 1995. Proteocephalus chamelensis n. sp. (Cestoda: Proteocephalidae) from the "Guavina" Gobiomorus maculatus (Osteichthyes: Eleotrididae) in Chamela Bay, Jalisco, México. Journal of Parasitology, vol. 81, no. 5, p. 773-776.

POULIN, R., 1992. Determinants of host-specificity in parasites of freshwater fishes. International Journal for Parasitology, vol. 22 , no. 6 , p. $753-758$

PRIEMER, J., 1987. On the life-cycle of Proteocephalus exiguus (Cestoda) from Salmo gairdneri (Pisces). Helminthologia, vol. 24 , p. $75-85$.

RABELO, H. and ARAÚJO-LIMA, CARM., 2002. A dieta e o consumo diário de alimentos de Cichla monoculus na Amazônia central. Acta Amazônica, vol. 32, no. 4, p. 707-724.

REGO, AA., 2002. Cestóides proteocefalídeos parasitas de Pseudoplatystoma (Pisces, Pimelodidae) da América do Sul. Revista Brasileira de Zoociências, vol. 4, no. 2, p. 255-268.

REGO, AA. and PAVANELLI, GC., 1987. Cestóides proteocefalídeos do jaú, Paulicea luetkeni, peixe pimelodídeo do Brasil. Revista Brasileira de Biologia = Brazilian Journal of Biology, vol. 47, p. 357-361.

-, 1990. New species of proteocephalid cestodes in non siluriform fishes. Revista Brasileira de Biologia $=$ Brazilian Journal of Biology, vol. 50, p. 91-101.

REGO, AA., De CHAMBRIER, A., HANZELOVÁ, V., HOBERG, E., SCHOLZ, T., WEEKES, P. and ZEHNDER, M., 1998. Preliminary phylogenetic analysis of subfamilies of the Proteocephalidea (Eucestoda). In Annals of the Second International Workshop for Tapeworms Systematics, october 2-6, 1996, Lincoln, Nebraska. Systematic Parasitology, vol. 40, no. 1, p. 1-19.

REGO, AA., CHUBB, JC. and PAVANELLI, GC., 1999. Cestodes in South American freshwater teleost fishes: keys to genera and brief description of species. Revista Brasileira de Zoologia, vol. 16, p. 299-367.
RENO, PW., 1998. Factors involved in the dissemination of disease in fish populations. Journal of Aquatic Animal Health, vol. 10, p. 160-171.

SCHOLZ, T., 1987. On the occurrence of endoparasitic helminthes in perch (Perca fluviatilis L.) from the Mácha lake fishpond system, Czechoslovakia. Acta Universitatis CarolinaeBiologica, vol. 11, p. 301-318.

-, 1991, Studies on the development of the cestodes Proteocephalus neglectus La Rue, 1911 (Cestoda: Proteocephalidae) under experimental conditions. Folia Parasitologica, vol. 38, p. 39-55.

-, 1993. Development of Proteocephalus torulosus in the intermediate host under experimental condition. Journal of Helminthology, vol. 67, no. 4, p. 316-324.

-, 1999. Life cycle of species of Proteocephalus, parasites of fishes in the Palearctic Region: a review. Journal of Helminthology, vol. 73, no. 1, p. 1-19.

SCHOLZ, T., SPAKULOVÁ, M., SNABEL, V., KRÁLOVÁ, I. and HANZELOVÁ, V., 1997. A multidisciplinary approach to the systematics of Proteocephalus macrocephalus (Creplin, 1825) (Cestoda: Proteocephalidae). Systematic Parasitology, vol. 37 , no. 1, p. 1-12.

SCHOLZ, T., MARCOGLIESE, DJ., BOURQUE, JF., SKERIKOVÁ, A. and DOBSON, JJ., 2004. Occurrence of Proteocephalus tetrastomus (Rudolphi, 1810) (Cestoda: Proteocephalidae) in larval Rainbow Smelt (Osmerus mordax) in North America: Identification of a potential patogen confirmed. Journal of Parasitology, vol. 90, no. 2, p. 425-427.

TAKEMOTO, RM. and PAVANELLI, GC., 1996. Proteocephalidean cestodes in the freshwater fish Cichla monoculus from the Paraná River, Brazil. Studies on Neotropical Fauna and Environment, vol. 31, no. 2, p. 123-127.

-, 2000. Aspects of the ecology of proteocephalid cestodes parasites of Sorubim lima (Pimelodidae) of the upper Paraná river, Brazil. I. Structure and influence of host's size and sex. Revista Brasileira de Biologia = Brazilian Journal of Biology, vol. 60 , no. 4 , p. $577-584$.

WILLEMSE, JJ., 1969. The genus Proteocephalus in the Netherlands. Journal of Helminthology, vol. 43, no. 1, p. $207-222$.

WOODLAND, WNF., 1935. Some new proteocephalids and a ptychobothriid (Cestoda) from the Amazon. Proceedings of Zoological Society of London, vol. 105, p. 619-623. 